\title{
Kilogram-scale production of selenized glucose
}

Wenjian Zhou, ${ }^{\dagger}$ Peizi Li,${ }^{\dagger}$ Jian Liu,$\stackrel{\dagger}{ }$ and Lei $\mathrm{Yu}^{*}, \dagger$

†School of Chemistry and Chemical Engineering, Yangzhou University, Yangzhou, Jiangsu 225002, P. R. China

¥Sichuan Selewood Technology Company Limited, Chengdu 610218, China

\section{CONTENTS}

1. Additional experimental details. S2

2. XPS spectrum of the selenized glucose. S4

3. FT-IR spectra of the selenized glucose. S4

4. NMR spectra of the selenized glucose. .S5

5. Methods of the product quality analysis. .S6 


\section{Additional experimental details}

(1) Preparation of $\mathrm{Se} / \mathrm{C}$ from the commercialized selenized glucose: $50 \mathrm{~g}$ of the selenized glucose was sent into a pipe furnace, which was then charged with $\mathrm{N}_{2}$. The chemical was calcined at $500{ }^{\circ} \mathrm{C}$ for $5 \mathrm{~h}$ with $\mathrm{N}_{2}$ flow protection. After then, a black mass was obtained, which was grinded into powders to produce $19.6 \mathrm{~g}$ of $\mathrm{Se} / \mathrm{C}$.

(2) Se/C-catalyzed oxidation of $\beta$-ionone: To a glass pressure reaction tube, $1 \mathrm{mmol}$ of $\beta$-ionone, $10 \mathrm{mg}$ of $\mathrm{Se} / \mathrm{C}, 4 \mathrm{mmol} \mathrm{H}_{2} \mathrm{O}_{2}(30 \mathrm{w} / \mathrm{w} \%)$, a piece of magnetic bar and $1 \mathrm{~mL}$ EtOAc were added. The tube was then sealed and the mixture was stirred at $80{ }^{\circ} \mathrm{C}$ for $24 \mathrm{~h}$. After cooling to room temperature, the solvent was removed by distillation under reduced pressure with a rotary evaporator and the residue was separated by the preparative thin layer chromatography (GF254 silica plate, eluent: petroleum ether/EtOAc $=10 / 1)$ and it produced $137.5 \mathrm{mg}$ of (E)-4-(2,2,6-trimethyl-7-oxabicyclo[4.1.0]heptan-1-yl)but-3-en-2-one （yielding $66 \%)$

(3) Details for the bio-activity tests of $\mathrm{Se} / \mathrm{C}$ : A series of aqueous $\mathrm{Se} / \mathrm{C}$ suspensions with the concentrations at 0 (blank sample for comparison), 0.01, 0.1, 1, 10 and $100 \mu \mathrm{g} / \mathrm{mL}$ were initially prepared. The samples were treated by wet-heat sterilization and then cooled to room temperature. To every sample, $200 \mu \mathrm{L}$ of $X c c$ bacteria liquid prepared under shaking cultivation was added and the mixture was shook $(150 \mathrm{r} / \mathrm{min})$ at $28{ }^{\circ} \mathrm{C}$ for $56 \mathrm{~h}$. The bacteria liquids were then diluted with sterilized deionized water to $10^{6}, 10^{7}, 10^{8}$ and $10^{9}$ times respectively and 
they were then subjected to the prefabricated medium plate $(10 \mu \mathrm{L}$ for each test and repeated for 4 times). After drying, the plate was kept at $28{ }^{\circ} \mathrm{C}$ for bacterial culture and the numbers of the bacterial colonies were counted. The results were given in Table $\mathrm{S} 1$ and the equation was found to be: $\mathrm{y}=0.0845 \ln (\mathrm{x})+0.3899$, i.e. $\mathrm{x}=\mathrm{e}^{\wedge}[(\mathrm{y}-0.3899) / 0.0845]$. When the inhibition ratio $=50 \%$, i.e. $\mathrm{y}=0.5, \mathrm{x}=$ $\mathrm{e}^{\wedge}[(0.5-0.3899) / 0.0845]=\mathrm{e}^{\wedge} 1.303=3.68(\mathrm{mg} / \mathrm{L})=3.68(\mu \mathrm{g} / \mathrm{mL})$.

Table S1. Bio-activity test of Se/C vs. Xcc.

\begin{tabular}{|c|c|c|}
\hline Se/C concentration(mg/L) $(\mathrm{x})$ & Clone amount $^{\mathrm{a}}$ & Inhibition ratio (y) $^{\mathrm{CK}}$ \\
\hline 0.01 & $463.2 \pm 28.2387$ & - \\
\hline 0.1 & $435.4 \pm 25.2584$ & $6.01 \%$ \\
\hline 1 & $402.6 \pm 18.4721$ & $13.08 \%$ \\
\hline 10 & $318.6 \pm 10.1083$ & $31.22 \%$ \\
\hline 100 & $140.5 \pm 5.3631$ & $69.67 \%$ \\
\hline & $115.9 \pm 4.0572$ & $74.98 \%$ \\
\hline
\end{tabular}

${ }^{\text {a }}$ Diluted to $10^{9}$ times in $10 \mu \mathrm{L}$ liquid. 
XPS spectrum of the selenized glucose

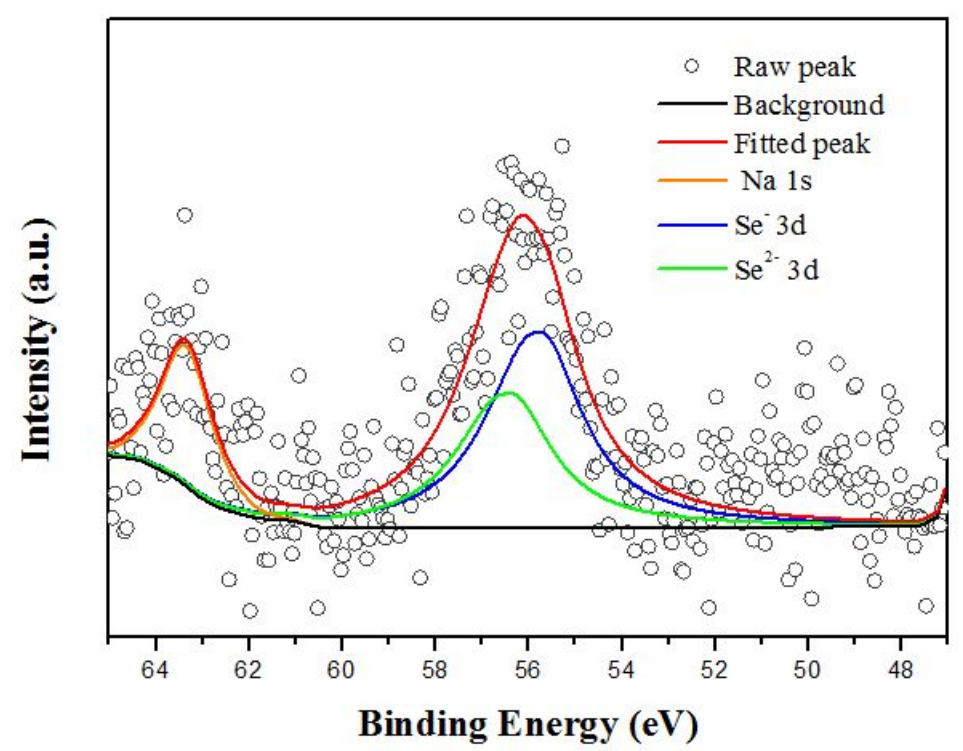

Figure S1. XPS spectrum of the selenized glucose.

FT-IR spectra of the selenized glucose

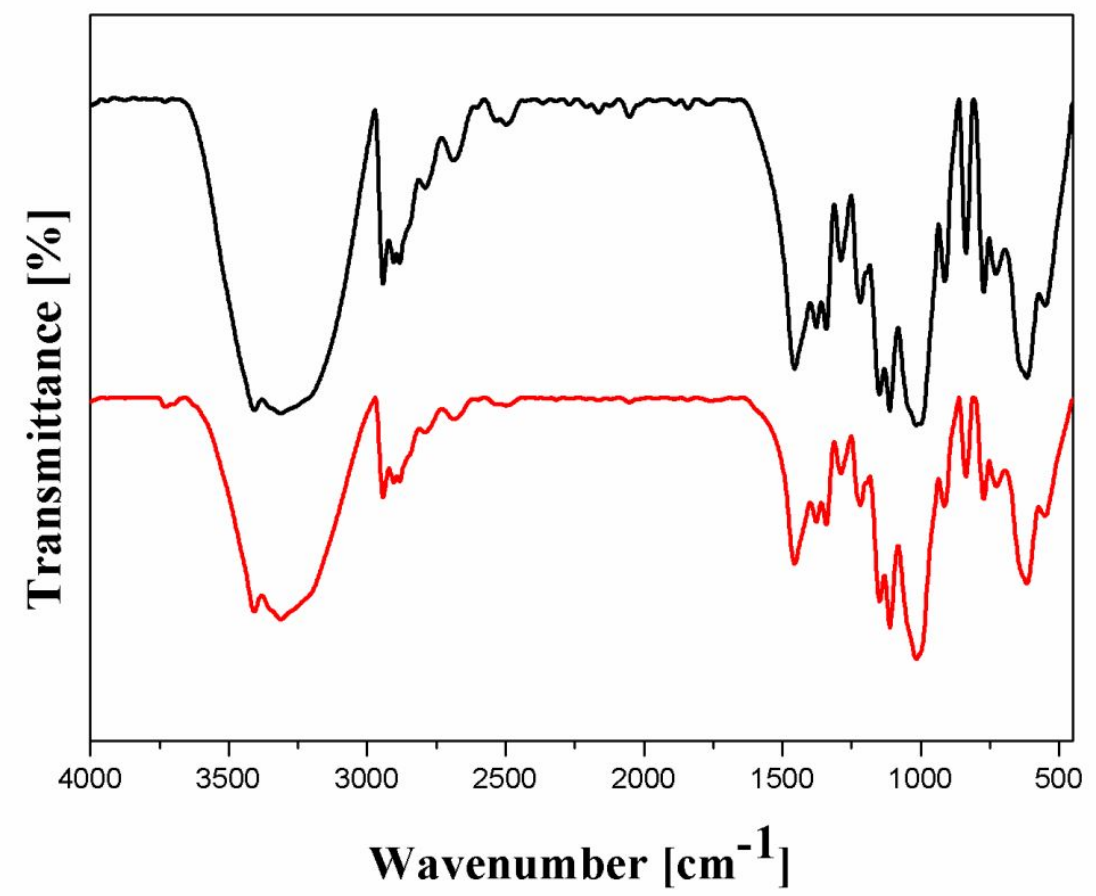

Figure S2. FT-IR spectra of glucose (black) and selenized glucose (red). 
NMR spectra of the selenized glucose

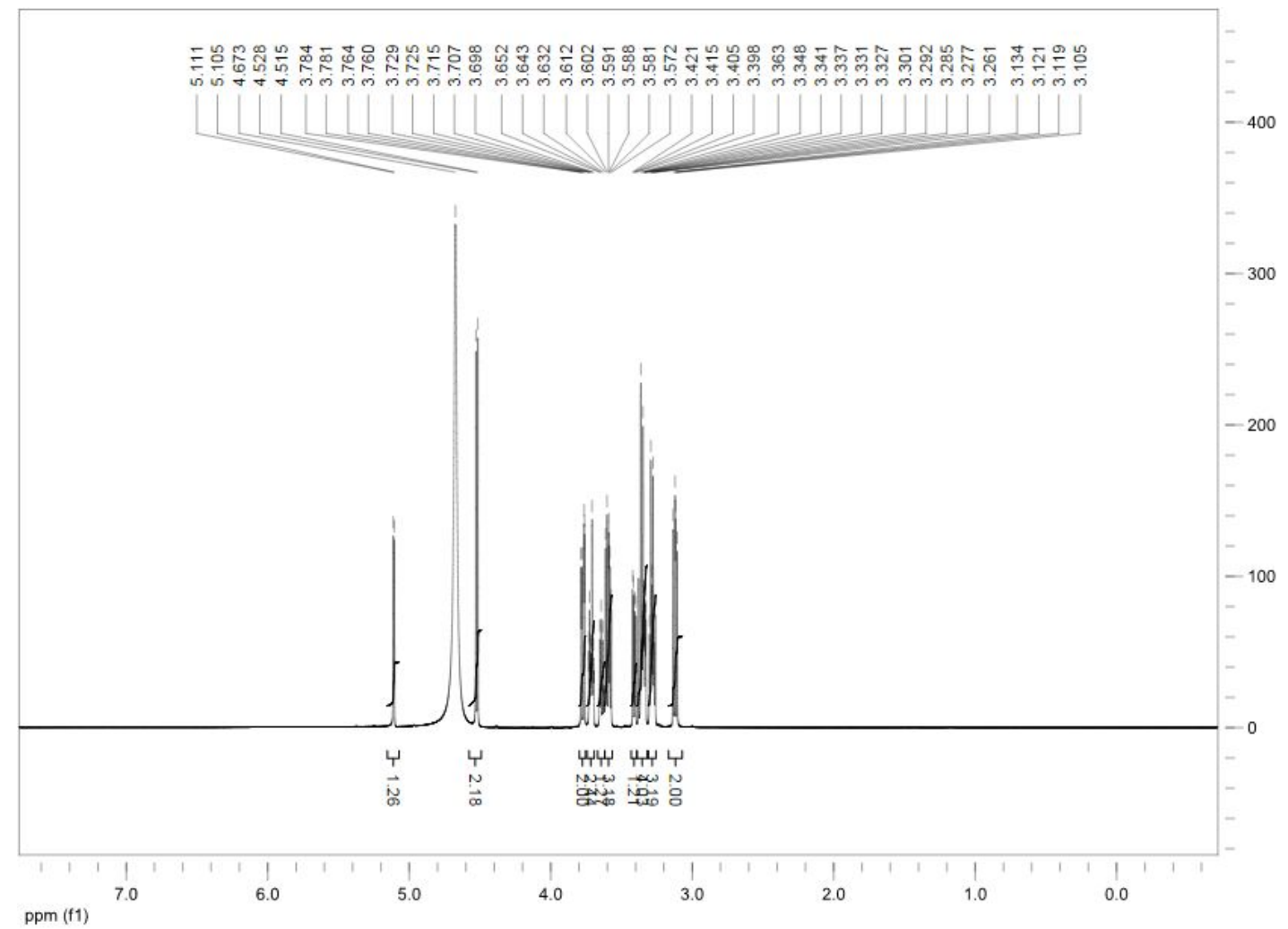

Figure S3. ${ }^{1} \mathrm{H}$ NMR $\left(600 \mathrm{MHz}, \mathrm{D}_{2} \mathrm{O}\right)$ spectra.

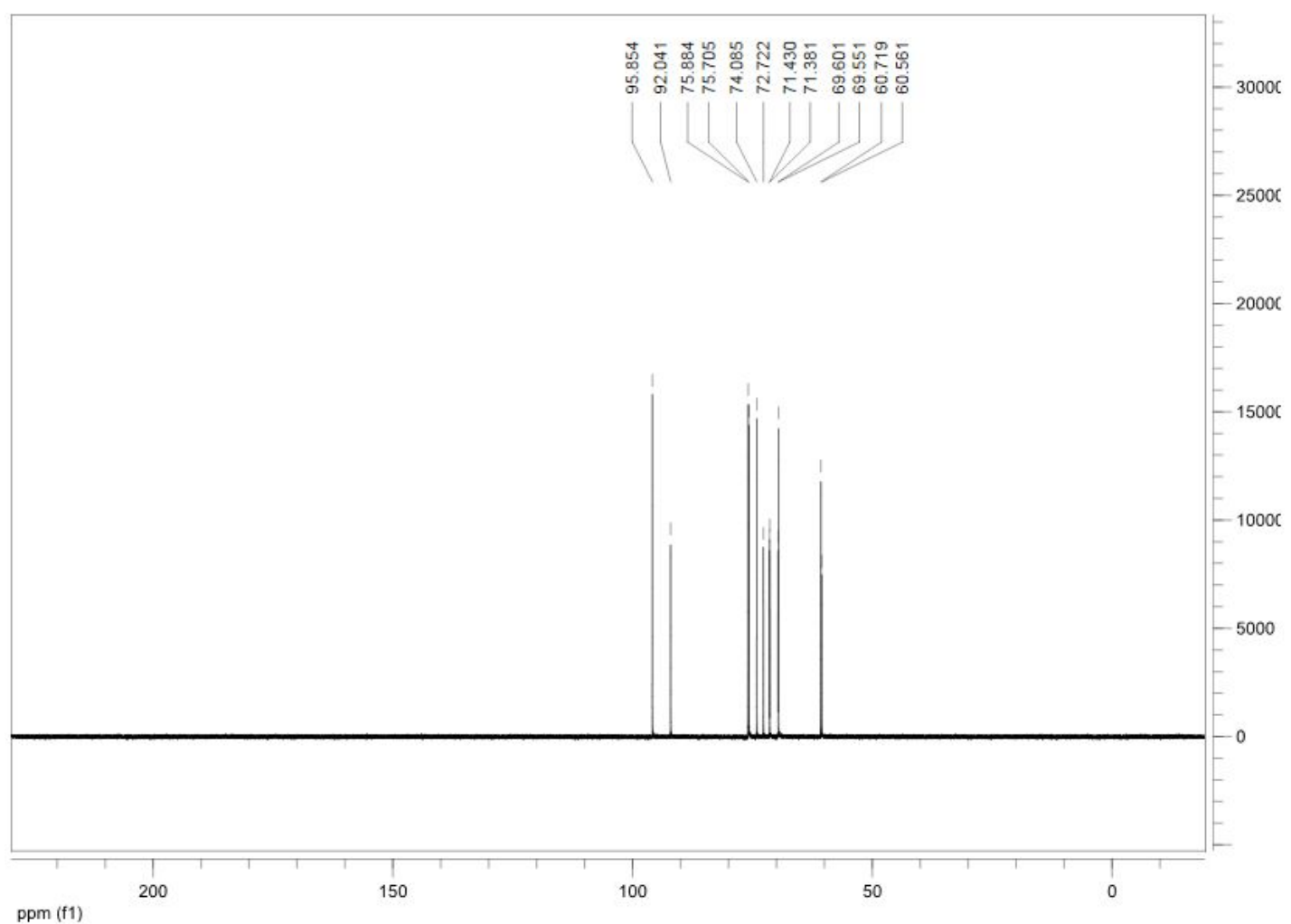

Figure S4. ${ }^{13} \mathrm{C}$ NMR $\left(150 \mathrm{MHz}, \mathrm{D}_{2} \mathrm{O}\right)$ spectra. 
Methods of the product quality analysis

Table S2. Product Quality Analysis ${ }^{a}$

\begin{tabular}{|c|c|c|c|}
\hline entry & item & method & remarks \\
\hline 1 & purity & weight loss method & $\begin{aligned} \text { purity }= & 100 \%-\text { impurity } \\
& \text { contents }\end{aligned}$ \\
\hline 2 & $\mathrm{Se}$ & $\begin{array}{l}\text { inductively coupled plasma } \\
\text { emission spectrometry } \\
\text { (ICPES) }\end{array}$ & - \\
\hline \multirow[t]{2}{*}{3} & Se valent & $\begin{array}{l}\text { X-ray photoelectron } \\
\text { spectroscopy }\end{array}$ & - \\
\hline & & (XPS) & \\
\hline 4 & moisture & Karl Fischer method & - \\
\hline 5 & insoluble matter & weighing method & $\begin{array}{l}\text { The insoluble matter was } \\
\text { separated by filtration and } \\
\text { weighted. }\end{array}$ \\
\hline 6 & $\mathrm{Mg}$ & ICPES & - \\
\hline 7 & $\mathrm{Fe}$ & ICPES & - \\
\hline 8 & $\mathrm{~Pb}$ & ICPES & - \\
\hline 9 & $\mathrm{Cu}$ & ICPES & - \\
\hline 10 & $\mathrm{Cr}$ & ICPES & - \\
\hline 11 & $\mathrm{Ni}$ & ICPES & - \\
\hline 12 & $\mathrm{Cd}$ & ICPES & - \\
\hline 13 & $\mathrm{Zn}$ & ICPES & - \\
\hline
\end{tabular}

${ }^{a}$ Methods were performed according to the enterprise standard. 